\title{
ABUNDANCE OF THREE SPECIES OF ISOPODA (PERACARIDA, ISOPODA) ASSOCIATED WITH A CORAL REEF ENVIRONMENT IN PACIFIC MEXICO
}

\author{
BY \\ ROBERTO CRUZ-GARCÍA ${ }^{1}$ ), AMILCAR L. CUPUL-MAGAÑA ${ }^{1}$ ), MICHEL \\ E. HENDRICKX ${ }^{2}$ ) and ALMA P. RODRÍGUEZ-TRONCOSO ${ }^{1,3}$ ) \\ ${ }^{1}$ ) Centro Universitario de la Costa, Universidad de Guadalajara, Av. Universidad 203, \\ Del. Ixtapa, Jalisco 48280, Mexico \\ 2 ) Unidad Académica Mazatlán, Universidad Nacional Autónoma de México, \\ Instituto de Ciencias del Mar y Limnología, P.O. Box 811, Mazatlán, Sinaloa 82000, Mexico
}

\begin{abstract}
Fragments of dead coral belonging to Pocillopora Lamarck, 1816 were used during a 1-year period as artificial micro-habitats and positioned at a coral reef community at Islas Marietas, Bahía Banderas, on the west coast of Mexico, to attract and capture isopods. Three species of isopods, totaling 961 specimens were collected. The dominant species was Joeropsis dubia (Menzies, 1951) (Joeropsididae) (83.03\% of the total number of specimens), followed by Califanthura squamosissima (Menzies, 1951) (Paranthuridae) (9.78\%), and Paracerceis sculpta (Holmes, 1904) (Sphaeromatidae) $(7.18 \%)$. The average density of isopods was of $12.0 \times 10^{-2}$ ind. $\cdot \mathrm{cm}^{-2}$. A positive relationship between water temperature and total density of individuals during the sampling period was found. Annual water temperature changes influenced the abundance of each species in a similar way, with the higher abundances associated to the lower temperatures, which is also related to an increase in primary productivity and the presence of upwellings in the area.
\end{abstract}

Key words. - Isopoda, western Mexico, coral reefs community

\section{RÉSUMÉ}

Des fragments de coraux morts du genre Pocillopora Lamarck, 1816 ont été disposés comme un micro-habitat artificiel pour une période d'un an à proximité d'un récif corallien près des îles Marietas, dans la baie de Banderas, le long de la côte ouest du Mexique, afin d'attirer et de capturer des isopodes. Trois espèces d'isopodes, totalisant 961 spécimens, ont été récoltées. L'espèce dominante, Joeropsis dubia (Menzies, 1951) (Joeropsididae), représentait 83,03\% des spécimens, suivi de Califanthura squamosissima (Menzies, 1951) (Paranthuridae) $(9,78 \%$ ) et de Paracerceis sculpta (Holmes, 1904) (Sphaeromatidae) (7,18\%). La densité moyenne des isopodes fut de 12,0 $\times$ $10^{-2}$ ind. $\cdot \mathrm{cm}^{-2}$. Une relation positive a été obtenue entre la température de l'eau et la densité totale

3 ) Corresponding author; e-mail: pao.rodriguezt@gmail.com 
des individus au cours de la période d'échantillonnage, et les variations de la température de l'eau ont eu une influence identique sur l'abondance de chaque espèce.

Mots clés. - Isopoda, côte ouest du Mexique, récifs

\section{INTRODUCTION}

With about 6400 described species, isopods represent approximately 13\% of all species of crustaceans described with the ability to live in marine, freshwater, and terrestrial habitats (Appeltans et al., 2012). The marine isopods include 3154 species (Poore \& Bruce, 2012) distributed from the intertidal to great depths, either free-living or associated with other organisms (e.g., algae, sponges, corals, fishes). They inhabit different substrata such as wood, rock, and sand among others, and some species are classified as true parasites (Brusca \& Iverson, 1985; Grutter, 1999; López et al., 2012) even of other crustaceans (Williams \& Boyko, 2012). There is a large series of contributions dealing with the taxonomy and distribution of marine isopods occurring in the tropical eastern Pacific where about 420 species have been recorded to date (see Espinosa-Pérez \& Hendrickx, 2001a, 2002a, 2006; Hendrickx, 2008). With 81 species recorded, the Gulf of California, one of the most diverse ecosystems within the East Pacific, is particularly species-rich (Brusca \& Iverson, 1985; Campos \& Villareal, 2008); however, coral reefs are scarce in this region. The Cabo Pulmo and Bahía Banderas areas are known for their welldeveloped coral reefs (Brusca, 1980; Carriquiry \& Reyes-Bonilla, 1997; ReyesBonilla \& López-Pérez, 1998), but little is known about their Peracarida fauna. Consequently, the number of species of isopods in this enclosed area could be much higher than presently known.

Coral reefs are among the most productive natural marine communities and serve as shelter and as a food source for a large series of species, including fishes and invertebrates (Sheppard, 2010). One of the most important coral community in the Mexican Pacific is found at Islas Marietas, where many coral species have been recorded. Most representative species are the branching members of the genus Pocillopora, i.e., P. verrucosa (Ellis \& Solander, 1786), P. damicornis (Linnaeus, 1758) and $P$. capitata Verrill, 1864, and the sub-massive and incrusting corals such as Pavona and Porites (Reyes-Bonilla \& López-Pérez, 1998; Carriquiry et al., 2001). In addition to the presence of coral species, which are locally protected, a high diversity of fishes and invertebrates are associated to these reefs (CONANP, 2007). As in other regions of the world, corals serve as refuges for species of isopods (see Glynn \& Enochs, 2011; Poore \& Bruce, 2012). However, these communities are difficult to sample due to the fact that in most countries where coral reefs occur, they benefit from special protection by law as they are important 
ecosystems that provide for social and ecological services (Alquezar \& Boyd, 2007). Mexico is no exception to this and sampling in coral reefs ecosystems is strictly regulated by federal laws and enforcement (CONANP, 2007). This partly explains why there are so few data related to the presence of isopods or other species within coral reefs in the Mexican Pacific compared to other regions (see Kensley, 1984; Müller, 1992, 1993a, b).

Isopods associated with coral-reefs are highly diversified and belong to several families (e.g., Anthuridae, Parathuridae, Cirolanidae, Sphaeromatidae, Janiridae, Munnidae, Stenetriidae) (see Müller, 1991, 1993a, b, 2008; Müller \& Salvat, 1993; Kensley, 2008; Poore, 2009; Winfield et al., 2010). Coral reefs are also the habitat for species of Isopoda (e.g., Cymothoidae, Gnathiidae) selectively associated with reef fish species (see Pattipeiluhu \& Gill, 1998; Sullivan \& Stimmelmayer, 2008).

With a view to detect the presence of isopods in a natural environment where coral reefs constitute a major potential refugee for cryptic species, a series of artificially-built coral debris structures were deployed in the vicinity of a coral reef. This contribution reports on the species that were collected in these structures and on their abundance.

\section{MATERIAL AND METHODS}

Samples of isopods were obtained from Islas Marietas National Park $\left(20^{\circ} 42^{\prime} 47^{\prime \prime}-20^{\circ} 41^{\prime} 11^{\prime \prime} \mathrm{N}, 105^{\circ} 33^{\prime} 18^{\prime \prime}-105^{\circ} 36^{\prime} 00^{\prime \prime} \mathrm{W}\right)$, Bahía de Banderas, off the coast of Nayarit, Mexico. The Islas Marietas complex is located near shore (aproximately $8 \mathrm{~km}$ ) and consists of two small islands of volcanic origin, Isla Redonda and Isla Larga (fig. 1) (CONANP, 2007), and in an area under the influence of the California Current, the Costa Rica Coastal Current, and the water of the Gulf of California (Wyrtki, 1965).

Sampling was performed every two months from March 2011 to February 2012 at one reef patch located at Isla Larga, where all the species of Pocillopora reported for the area are present (Reyes-Bonilla et al., 2005). Two semi-spherical concrete structures with 6 steel rods each were placed on a sandy bottom, next to the healthy Pocillopora coral colonies six months before sampling. The site is a protected shallow natural reserve where diving and visits are prohibited (CONANP, 2007). In order to follow the federal regulations which forbid direct sampling in coral reefs habitats, $5 \mathrm{~cm}$ long fragments of dead coral belonging to the genus Pocillopora were used as a micro-habitat to attract isopods living in the area. Selected fragments of dead coral were sampled in situ and submerged in a $10 \%$ solution of sodium hypochlorite for $24 \mathrm{~h}$ to eliminate organic material. Clean fragments were washed with running fresh water for 8 hours and dried in an oven 


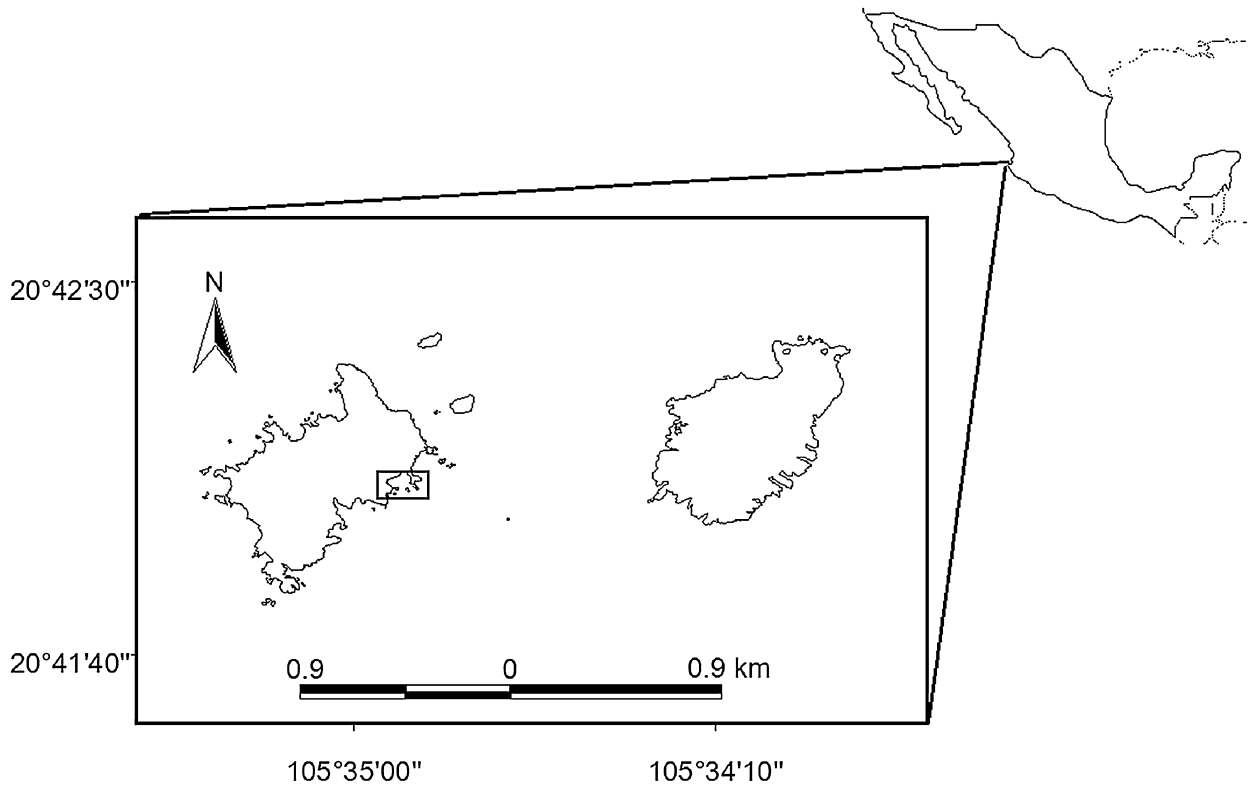

Fig. 1. Location of Islas Marietas National Park, Bahía de Banderas, Nayarit, Mexico. The sampling area is marked with a rectangle.

$\left(60^{\circ} \mathrm{C}\right)$ for $24 \mathrm{~h}$. A series of 24 coral fragments were attached to the steel rods (288 fragments in total) fixed vertically in the concrete bases. These two structures were submerged at $5 \mathrm{~m}$ depth as close as possible to natural coral reef structures. During each bimonthly sampling operation, the coral fragments attached to one rod of each structure were collected. To avoid loss of associated fauna, each fragment was introduced into a plastic bag in situ. Closed bags were transported to the laboratory in an ice box filled with sea water and deep-frozen $\left(-20^{\circ} \mathrm{C}\right)$ until further processing. After being defrosted, each fragment was carefully examined under magnification and all specimens associated with it were identified and counted. Identified specimens were preserved in a $70 \%$ ethanol solution. In order to evaluate the relative abundance of isopods, the surface of each coral fragment was estimated using the method described by Marsh (1970) in which area is calculated with an aluminum foil technique. Density data were expressed as number of individuals per $\mathrm{cm}^{2}$. The Shannon-Wiener $\left(J^{\prime}\right)$ diversity index and Margalef richness index (Cardona, 2007) were calculated with the resulting data. Water temperature was recorded at bottom level with an in situ HOBO Pendandt ${ }^{\circledR}$ thermograph and the temperature data are expressed as the mean temperature \pm standard error.

Statistical analyses were performed with the Sigma Plot V.11.0 software for Windows. A one-way ANOVA $(p<0.001)$ was used to test possible relationships between species total abundance and temperature. As data from the three species 
were not normally distributed or homogeneous, a Kruskal-Wallis test was performed in order to test the impact of temperature over the three species. A Dunn a posteriori test was employed to determine significant differences $(\alpha=0.05)$.

\section{RESULTS}

Three species of isopods were obtained from the samples: Califanthura squamosissima (Menzies, 1951) (Paranthuridae), Joeropsis dubia (Menzies, 1951) (Joeropsididae), and Paracerceis sculpta (Holmes, 1904) (Sphaeromatidae). A total of 961 specimens were collected. Joeropsis dubia was the most abundant species (83.03\% of total), followed by C. squamosissima (9.78\%) and P. sculpta (7.18\%). Considering the entire series of samples, the average density of isopods was of $12.0 \times 10^{-2}$ ind. $\cdot \mathrm{cm}^{-2}$, with a diversity $J^{\prime}=0.567$ and a richness value of 0.291 . The highest density was observed in November-December $\left(22.3 \times 10^{-2}\right.$ ind. $\left.\cdot \mathrm{cm}^{-2}\right)$ and the lowest density $\left(5.4 \times 10^{-2}\right.$ ind. $\left.\cdot \mathrm{cm}^{-2}\right)$ in July-August.

Two of the three species, J. dubia and C. squamosissima, dominated the samples. Two species, J. dubia and P. sculpta, were present in all samples throughout the survey while $C$. squamossissima was found in 5 out of 6 sampling periods. The average bimonthly density for each species indicates that J. dubia was by far the dominant species in the samples during almost the entire survey, except in March-April when C. squamosissima was the most abundant species (fig. 2). Maximum abundance for $J$. dubia was observed in the November-December sample $\left(22.105 \times 10^{-2}\right.$ ind. $\left.\cdot \mathrm{cm}^{-2}\right)$ while in the rest of the samples density for this species was always below $10 \times 10^{-2}$ ind. $\cdot \mathrm{cm}^{-2}$. The maximum density for C. squamosissima $\left(6.949 \times 10^{-2}\right.$ ind. $\left.\cdot \mathrm{cm}^{-2}\right)$ and P. sculpta $\left(6.508 \times 10^{-2}\right.$ ind. . $\mathrm{cm}^{-2}$ ) was similar and observed in the March-April samples.

Sea water temperature showed strong variation throughout the year (fig. 2) with highest values recorded in July-August $\left(30.34 \pm 0.01^{\circ} \mathrm{C}\right)$ and SeptemberOctober $\left(30.56 \pm 0.01^{\circ} \mathrm{C}\right)$. Overall lowest temperature was observed in MarchApril $\left(20.95 \pm 0.02^{\circ} \mathrm{C}\right)$. A one-way ANOVA showed a positive relationship between water temperature and total density of individuals during the sampling period $(F=28.227, p<0.001)$. In addition, annual water temperature changes influenced the abundance of each species (Kruskal-Wallis, $H=18.233, p<0.001$ ) in a similar way (Dunn test $p<0.05$ ).

\section{DISCUSSION}

Marine isopods are widely distributed worldwide and are highly diverse in coral reefs (Poore \& Bruce, 2012). Kensley (1988) estimated that there might be as 


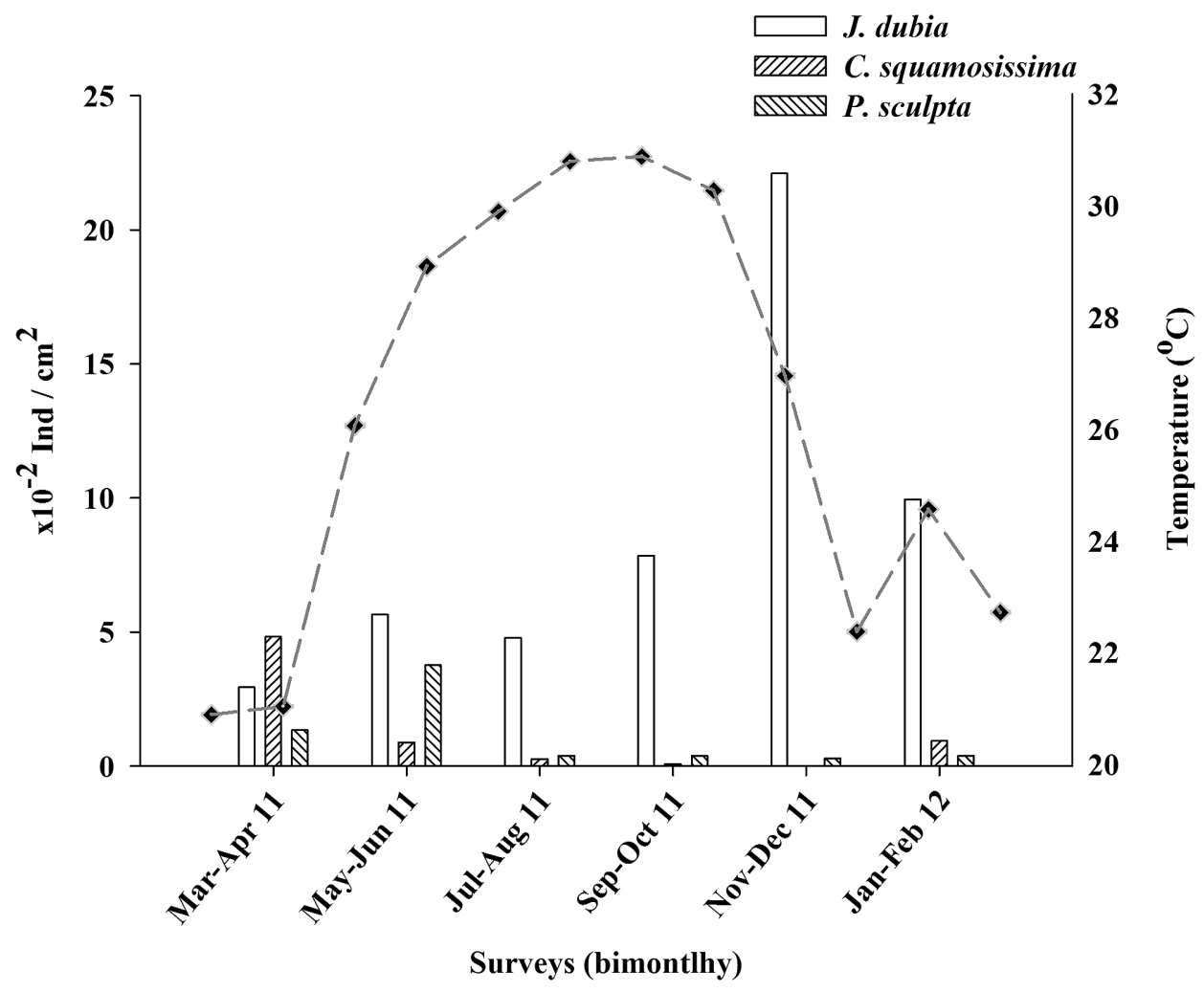

Fig. 2. Relation of the abundance $\left(\times 10^{-2}\right.$ ind. $\left.\cdot \mathrm{cm}^{-2}\right)$ of the three species of isopods and annual variation of surface water temperature $\left({ }^{\circ} \mathrm{C}\right) \pm$ SE from March 2011 to February 2012 at the sampling site.

many as 13000 isopod species in the world's coral reefs, with a high degree of endemicity (up to $80 \%$ of endemism for the Eastern-Central Pacific islands). The three species collected during this survey are all known from California, U.S.A., and extend their southern distribution to the Gulf of California or further south (Carvacho \& Hassmann, 1984; Espinosa-Pérez \& Hendrickx, 2001a, 2002b, 2006; Campos \& Villareal, 2008). Their wide distribution and their presence in the study area can be explained by the fact that the islands are close to shore and under the influence of coastal processes, including littoral species dispersion.

Jaeropsidae are distributed worldwide and are a common group of marine isopods (Schultz, 1969). Jaeropsis dubia is the only species of this family on record for the entire western coast of Mexico, including the Gulf of California. Two other species (J. concava (Schutz, 1966) and J. lobata (Richardson, 1899)) are reported from California but so far have not been collected in the Mexican portion of the California Province or further south. The presence of $J$. dubia at Islas Marietas 
corresponds to the first record of this isopod for the central Mexican Pacific and in a coral substrate, where they are generally rare and usually collected from adjacent off-reef areas (Poore \& Bruce, 2012).

Califanthura squamosissima and Paracerceis sculpta are also known from California and throughout the Gulf of California, the former south to Oaxaca and the latter to Michoacán, Mexico; P. sculpta has also been reported from the East and West Atlantic and the Mediterranean as an invasive species (Carvacho \& Hassmann, 1984; Espinosa-Pérez \& Hendrickx, 2001, 2002b; Campos \& Villareal, 2008). Califanthura squamosissima is also the only species of the genus known from the west coast of Mexico. Paracerceis sculpta is one of the three species of the genus occurring along the west coast of Mexico and certainly the most frequently found in the intertidal zone (Schultz, 1969; Espinosa-Pérez \& Hendrickx, 2002a, b; López et al., 2012).

Records presented herein are directly related to the presence of a nearby living coral reef habitat and the use of fragments of dead coral as a collecting method simulated the reef matrix, which is the most abundant substrate available for recruitment in coral ecosystems. Consequently, the results provide a good indication that these three species are indeed associated with the coral reef community. The dominance of $J$. dubia, a rarely reported species, is remarkable. This could indicate that it represents a key element of the adjacent reef bioscenosis, in a similar way as what has been described by Castellanos et al. (2003) for a reef area in the Mediterranean Sea, where J. brevicornis was one of the three dominant species. Although J. dubia might represent a case of early colonizer, the fact that it was present in the samples throughout the study period is probably linked to its ubiquity and abundance in the area.

The geographic location of Islas Marietas favours the presence of species associated with different zoogeographic provinces. Indeed, it is located at the southern edge of the Cortés Province (Gulf of California and southern tip of the Baja California Peninsula), a predominantly tropical-subtropical ecosystem, at the northern edge of the Mexican Province, a typically tropical area, and is also under the seasonal influence of the warm-temperate California Current (Wyrtki, 1965; Lavín \& Marinone, 2003; Hendrickx et al., 2005). The confluence of these three provinces and their respective fauna in a transition area under the influence of both warm temperate and tropical water masses favours a high local biodiversity. The number of species reported herein (three) is therefore very low considering that coral reefs are particularly complex ecosystems and can host a high marine isopods diversity (Poore \& Bruce, 2012). Further studies aimed at collecting a larger sample of isopods associated with the Islas Marietas corals is therefore necessary, perhaps using non invasive and non destructive traps located directly within the coral community. 
This work represents the first record of isopods in the study area and also represents the first local ecological data for the entire group. The annual changes in abundance of marine invertebrates are clearly associated with temperature fluctuations (Sanford \& Kelly, 2011), thus the seasonal temperature changes is a key factor that determines the presence and density of the different species. Islas Marietas is located at the southern limit of the Sea of Cortés sub-tropical/tropical Province and the area is under the influence of the California Current in the winter and spring (Lavín \& Marinone, 2003). It could therefore represent the distribution limit for north-temperate species.

Isopods are important contributors to biodiversity and biotic resources, and they play an important role in recycling organic matter (Schultz, 1969) making it available for higher trophic groups (López et al., 2012). Coral reef communities are very complex and large series of isopods, not detected by the method used during our study, is likely to be hidden and associated to algae or other invertebrates (e.g., sponges, anemones, soft corals, hermit crabs shells). The study of the species, however, will request further non-destructive methods. Despite this, and considering the local importance of the Islas Marietas National Park as a refugee for coral reefs communities, the year-long presence of isopods increases our knowledge on the biodiversity in this ecosystem.

\section{ACKNOWLEDGEMENTS}

The present work was supported by a posdoctoral fellowship to APRT PROMEP-F/47578-0 and by the project "Evaluación y monitoreo del efecto del Cambio Climático sobre las comunidades coralinas del Pacífico Central Mexicano" (P/PIFI-2010-14MSU0010Z-10) to ACM. Also, the authors thank the authorities from Islas Marietas National Park (CONANP) for the assistance and use of facilities during the sampling. Finally, the authors would like to thank Mr. Jim Marlatt for reviewing the English.

\section{REFERENCES}

AlqueZar, R. \& W. Boyd, 2007. Development of rapid cost effective coral survey techniques: tools for management and conservation planning. J. Coast. Conserv., 11: 105-119.

Appeltans, W., S. T. Ahyong, G. Anderson, M. V. Angel, T. Artois, N. Bailly, R. BamBer, A. Barber, I. Bartsch, A. Berta, M. Błazewicz-Paszkowycz, P. Bock, G. Boxshall, C. B. Boy Ko, S. N. Brandao, R. A. Bray, N. L. Bruce, S. D. Cairns, T. Y. Chan, L. Cheng, A. G. Collins, T. Cribb, M. Curini-Galletti, F. DahdouhGuebas, P. J. F. Davie, M. N. Dawson, O. De Clerck, W. Decock, S. De Grave, N. J. De Voogd, D. P. Domning, C. C. Emig, C. Erseus, W. Eschmeyer, K. Fauchald, D. G. Fautin, S. W. Feist, C. H. J. M. Fransen, H. Furuya, O. Garcia-Alvarez, 
S. Gerken, D. Gibson, A. Gittenberger, S. Gofas, L. Gomez-Daglio, D. P. Gordon, M. D. Guiry, F. Hernandez, B. W. Hoeksema, R. R. Hopcroft, D. Jaume, P. Kirk, N. Koedam, S. Koenemann, J. B. Kolb, R. M. Kristensen, A. Kroh, G. LAmbert, D. B. Lazarus, R. Lemaitre, M. Longshaw, J. LOWRY, E. MacPherson, L. P. Madin, C. Mah, G. Mapstone, P. A. Mclaughlin, J. Mees, K. Meland, C. G. Messing, C. E. Mills, T. N. Molodtsova, R. Mooi, B. Neuhaus, P. K. L. Ng, C. Nielsen, J. Norenburg, D. M. Opresko, M. Osawa, G. Paulay, W. PerRin, J. F. Pilger, G. C. B. Poore, P. Pugh, G. B. Read, J. D. Reimer, M. Rius, R. M. Rocha, J. I. Saiz-Salinas, V. Scarabino, B. Schierwater, A. SchmidtRhaesa, K. E. Schnabel, M. Schotte, P. Schuchert, E. Schwabe, H. Segers, C. Self-Sullivan, N. Shenkar, V. Siegel, W. Sterrer, S. Stohr, B. Swalla, M. L. Tasker, E. V. Thuesen, T. Timm, M. A. Todaro, X. Turon, S. Tyler, P. Uetz, J. VAN DER LAND, B. VANhOorne, L. P. VAn OfWEgen, R. W. M. VAN Soest, J. Vanaverbeke, G. Walker-Smith, T. C. Walter, A. Warren, G. C. Williams, S. P. Wilson \& M. J. Costello, 2012. The magnitude of global marine species diversity. Current Biol., 22: 2189-2202.

BRUSCA, R. C., 1980. Common invertebrates of the Gulf of California: 1-513. (The University of Arizona Press, Tucson, AZ).

BruscA, R. C. \& E. W. IVERSon, 1985. A guide to the marine isopod Crustacea of Pacific Costa Rica. Rev. Biol. Trop., 33: 1-77.

CAmpos, E. \& E. Villareal, 2008. Isópodos litorales y de aguas someras de la bahía de Todos los Santos, Baja California, México. Rev. Mex. Biodiv., 79: 347-354.

CARdona, L., 2007. Biodiversidad: todas las claves: 1-208. (Océano Ambar, Mexico).

CARdona, L. \& H. Reyes-Bonilla, 2007. Community structure and geographic distribution of the coral reefs of Nayarit, Mexican Pacific. Ciencias Marinas, 23: 227-248.

Carriquiry, J. D., A. L. Cupul-Magaña, F. Rodríguez-Zaragoza \& P. Medina-Rosas, 2001. Coral bleaching and mortality in the Mexican Pacific during the 1997-98 El Niño and prediction from a remote sensing approach. Bull. Mar. Sci., 69: 237-249.

CARvacho, A. \& Y. HASSMAnN, 1984. Isópodos litorales de Oaxaca, Pacífico mexicano. Cahiers Biol. Mar., 24: 15-32.

Castellanos, C., S. Hernández-Vega \& J. Junoy, 2003. Isópodos marinos (Crustacea: Isopoda) de las islas Chafarinas (Mediterráneo occidental). Bol. Inst. Esp. Ocean., 19: 219233.

ConanP, 2007. Programa de Conservación y Manejo del Parque Nacional Islas Marietas: 1-155. (Comisión Nacional de Áreas Naturales Protegidas México).

Espinos A-PÉreZ, M. C. \& M. E. HENDRICKX, 2001. Checklist of isopods (Crustacea: Peracarida: Isopoda) from the eastern tropical Pacific. Belgian J. Zool., 131: 41-54.

$\ldots \ldots \&-\ldots, 2002 a$. Distribution and ecology of isopods (Crustacea: Peracarida: Isopoda) of the Pacific coast of Mexico. In: E. EscobAR-Briones \& F. AlvareZ, Modern approaches to the study of Crustacea: 95-104. (Kluwer/Plenum, New York, NY).

— — \& — - 2002b. The genus Paracerceis Hansen, 1905 (Crustacea: Isopoda: Sphaeromatidae) in the eastern tropical Pacific, with the description of a new species. Crustaceana, 74: 11691187.

— — \& — - 2006. A comparative analysis of biodiversity and distribution of shallow water marine isopods (Crustacea: Isopoda) from polar and temperate waters in the East Pacific. Belgian J. Zool., 136: 219-247.

GLYNN, P. W. \& C. ENOCHS, 2011. Invertebrates and their roles in coral reef ecosystems. In: Z. DUbinsky \& N. StAmbleR, Coral reefs: an ecosystem in transition: 275-279. (Springer, Berlin).

GRUTTER, A. S., 1999. Infestation dynamics of gnathiid isopod juveniles parasitic on the coral-reef fish Hemigymnus melapterus (Labridae). Mar. Biol., 135: 545-552. 
HendrickX, M. E., 2008. Rediscovery of Rocinela murilloi Brusca \& Iverson, 1985 (Crustacea: Isopoda: Aegidae) in the Gulf of California, Mexico, and ecological data associated with its capture. Crustaceana, 81: 1259-1262.

HendrickX, M. E., R. C. BRusCA \& L. T. Findley, 2005. A Distributional Checklist of the Macrofauna of the Gulf of California, Mexico. Part I. Invertebrates. [Listado y Distribución de la Macrofauna del Golfo de California, México, Parte I. Invertebrados]: 1-429. (ArizonaSonora Desert Museum, Tucson, AZ).

Kensley, B., 1984. The role of isopod crustaceans in the Reef Crest Community at Carrie Bow Cay, Belize. Mar. Ecol., 5: 29-44.

— - 1988. Estimates of species diversity of free-living marine isopod crustaceans on coral reefs. Coral Reefs., 17: 83-88.

—, 2008. The role of isopod crustaceans in the reef community at Carrie Bow Cay, Belize. Mar. Ecol., 5: 29-44.

LAVÍn, M. F. \& S. G. MARINONE, 2003. An overview of the physical oceanography of the Gulf of California. In: O. U. Velasco Fuentes, J. Sheinbaum \& J. OchoA (eds.), Nonlinear Processes in Geophysical Fluid Dynamics: 173-204. (Kluwer, Dordrecht).

López, B., M. Ortiz, I. Winfield \& S. ChÁZARo, 2012. Isópodos (Crustácea: Peracarida) asociados al área natural protegida Sistema Arrecifal Tuxpan-Lobos, Veracruz: 29. (VIII Reunión Alejandro Villalobos, Puerto Ángel, Oaxaca, México).

MARSH, J. A., 1970. Primary productivity of reef-building calcareous red algae. Ecology, 51: 255263.

MülleR, H. G., 1992. Anthuridae fron coral reefs at Bora Bora and Moorea, Society Islands, with description of three new species (Crustacea: Isopoda). Sencken. Biol., 72: 353-371.

— - 1991. Sphaeromatidae from coral reefs of the Society Islands, French Polynesia (Crustacea: Isopoda). Cah. Biol. Mar., 32: 83-104.

— - 1993a. Uromunna serricauda, a new species of asellote isopod crustacean from a coral reef in the Tioman Archipelago. Zool. Anz., 229: 219-226.

— $\ldots$, 1993b. Panthurid isopods from French Polynesian coral reefs, including descriptions of six new species (Crustacea: Peracarida). Cah. Biol. Mar., 34: 289-341.

_ _, 2008. Janiridae from Malaysian Coral Reefs, with description of two new species of Bagatus Nobili, 1906 and Carpias Richardson, 1902 (Crustacea: Isopoda: Asellota). Zoosys. Evol., 68: 331-343.

MülleR, H. G. \& B. SAlvat, 1993. Cirolanidae (Isopoda) from French Polynesian coral reefs: description of three new species. Crustaceana, 64: 197-220.

Pattipeiluhu, S. M. \& M. E. Gill, 1998. Ectoparasites of coral reef fishes and their value as biological indicators of pollution. Cakalele, 9: 25-29.

Poore, C. B., 2009. Leipanthura casuarina, new genus and species of anthurid isopod from Australian coral reefs without a "five-petalled" tail (Isopoda, Cymothoida, Anthuroidea). Zookeys, 18: 171-180.

Poore, C. B. \& N. L. BRUCE, 2012. Global diversity of marine isopods (except Asellota and crustacean symbionts). PLoS ONE, 7: e43529, DOI:10.1371/journal.pone.0043529

Reyes-Bonilla, H., L. Calderón-Aquilera, G. Cruz-Piñón, P. Medina-Rosas, R. López-Pérez, M. D. Herrero-Pérezul, A. L. Cupul-Magaña \& J. D. CarRIQUIRY, 2005. Atlas de corales pétreos (Anthozoa: Scleractinia) del Pacífico Mexicano: 1124. (CICESE, CONABIO, CONACYT, UABCS, UdeG, UdelM, Mexico).

REYes-BONILla, H. \& A. LÓPEZ-PÉREZ, 1998. Biogeography of the stony corals (Scleractinia) of the Mexican Pacific. Ciencias Marinas, 24: 211-224.

SAnDFORD, E. \& M. W. Kelly, 2011. Local adaptation in marine invertebrates. Ann. Rev. Mar. Sci., 3: 509-535.

SChUltZ, G. A., 1969. How to know the marine isopod crustaceans: 1-359. (W. M. C. Brown, St. Louis, MO). 
Sheppard, R. C., K. DaVy \& M. Pilling, 2010. The biology of coral reefs: 1-339. (Oxford University Press, New York, NY).

Sullivan, M. \& R. StimmelmayR, 2008. Cymothoid isopods on coral reef fishes in the near shore marine environment of St. Kitts, Lesser Antilles. In: Proceedings of the $11^{\text {th }}$ International Coral Reef Symposium, Ft. Lauderdale, Florida, 7-11 July 2008: 1394-1396.

Williams, J. D. \& C. B. BoYKo, 2012. The Global Diversity of Parasitic Isopods Associated with Crustacean Hosts (Isopoda: Bopyroidea and Cryptoniscoidea). PLoS ONE, 7: e35350, DOI:10.1371/journal.pone.0035350.

Winfield, I., S. Cházaro-Olvera, G. Horta-Puga, M. A. Lozano-Aburto \& V. AREnAS-Fuentes, 2010. Macrocrustáceos incrustantes en el Parque Nacional Sistema Arrecifal Veracruzano: biodiversidad, abundancia y distribución. Rev. Mex. Biodiv., 80: 165175.

WYRTKI, K., 1965. The annual and semiannual variation of sea surface temperature in the North Pacific Ocean. Limnol. Oceanogr., 3: 307-313. 